\title{
Kerapatan Clathria reinwardti dan Spheciospongia inconstans di Reef Flat Pulau Barranglompo, Kepulauan Spermonde, Makassar
}

\author{
Abdul Haris*, Widyastuti Umar, Reski Adiguna, Andi Muh. Agung Pratama \\ Fakultas IImu Kelautan dan Perikanan, Universitas Hasanuddin \\ Jl. Perintis Kemerdekaan No.KM. 10, Tamalanrea, Makassar, Sulawesi Selatan 90245 Indonesia \\ Email: haris.pagala65@gmail.com
}

\begin{abstract}
Density of Clathria reinwardti and Spheciospongia inconstans in Barranglompo Island Reef Flat, Spermonde Islands, Makassar
\end{abstract}

This study aims to determine the density of the sponges Clathria reinwardti and Spheciospongia inconstans in the reef flat of Barranglompo Island, Spermonde Archipelago, Makassar. The method used is belt transect using a roll meter as a reference for distance. The starting point of the roll meter $\pm 50 \mathrm{~m}$ from the shoreline is drawn perpendicularly to the end of the reef reef by 3 transects with a distance of $\pm 50 \mathrm{~m}$ between the roll meters. At each $25 \mathrm{~m}$ interval the observations were made using a belt transect size of $15 \mathrm{~m} \times 5 \mathrm{~m}$ as the limit of the observation. In each quadrant transect, were done first is documenting of each sponge then count the number of species present in each quadrant. The results showed that the density of Clathria reinwardti at stations I and II were 0.13 and $0.14 / \mathrm{m}^{2}$ respectively and were not significantly different, while those at stations III and IV were 0.25 and $0.31 / \mathrm{m}^{2}$ respectively and not significantly different. Station I and II are significantly different from stations III and IV. The density of Spheciospongia inconstans at station I $0.02 / \mathrm{m}^{2}$, station II 0.14 $/ \mathrm{m}^{2}$, station III $0.67 / \mathrm{m}^{2}$, and station IV $0.44 / \mathrm{m}^{2}$. The sponge density of S. inconstans between stations was significantly different. The density of $C$. reinwardti at stations III and IV was higher and significantly different than stations I and II, while the highest density of S. inconstans was found at station III followed by station IV, station II, and station I, and was significantly different among the four stations.

Keywords: Clathria reinwardti, Spheciospongia inconstans, Betl transect, Barranglompo.

\begin{abstract}
Abstrak
Penelitian ini bertujuan untuk mengetahui kerapatan spons Clathria reinwardti dan Spheciospongia inconstans di reef flat Pulau Barranglompo, Kepulauan Spermonde, Kota Makassar. Metode yang digunakan adalah belt transect dengan menggunakan roll meter sebagai acuan jarak. Titik awal roll meter $\pm 50 \mathrm{~m}$ dari garis pantai secara tegak lurus ditarik sampai batas akhir reef reef sebanyak 3 transek dengan jarak $\pm 50 \mathrm{~m}$ antar roll meter. Pada setiap interval $25 \mathrm{~m}$ pengamatan dilakukan menggunakan belt transect ukuran $15 \mathrm{~m} \times 5 \mathrm{~m}$ sebagai batasan pengamatan. Pada setiap transek kuadran, pertama-tama yang dilakukan adalah mengambil gambar setiap spons kemudian menghitung jumlah jenis yang terdapat pada setiap kuadran. Hasil penelitian, kerapatan spons Clathria reinwardti di stasiun I dan II masing-masing 0.13 dan $0.14 / \mathrm{m}^{2}$ dan tidak berbeda nyata, sedangkan di stasiun III dan IV masing-masing 0.25 dan $0.31 / \mathrm{m}^{2}$ dan tidak berbeda nyata. Stasiun I dan II berbeda nyata dengan stasiun III dan IV. Kerapatan spons Spheciospongia inconstans pada stasiun I $0.02 / \mathrm{m}^{2}$, stasiun II $0.14 / \mathrm{m}^{2}$, stasiun III $0.67 / \mathrm{m}^{2}$, dan stasiun IV $0.44 / \mathrm{m}^{2}$. Kerapatan spons Spheciospongia inconstans antar stasiun berbeda nyata. Kerapatan Clathria reinwardti pada stasiun III dan IV lebih tinggi dan berbeda nyata daripada stasiun I dan II, sedangkan kerapatan Spheciospongia inconstans tertinggi didapatkan pada stasiun III disusul kemudian stasiun IV, stasiun II, dan stasiun 1, serta berbeda nyata di antara keempat stasiun tersebut.
\end{abstract}

Kata kunci: Clathria reinwardti, Spheciospongia inconstans, Betl transect, Barranglompo. 


\section{PENDAHULUAN}

Clathria reinwardti dan Spheciospongia inconstans adalah spons yang umumnya hidup pada substrat berpasir, berbeda dengan spons pada umumnya, yang hidup pada substrat keras pada karang-karang mati atau hidup. Spons ini tumbuh dengan membenamkan sebagian tubuhnya ke dalam pasir pada ekosistem padang lamun maupun terumbu karang. C. reinwardti memiliki bentuk tubuh yang bercabang tidak teratur dan umumnya berwarna kekuningan, kuning sampai oranye (Hooper et al., 2000), sedangkan $S$. inconstans adalah spons yang umumnya berwarna coklat, bentuk tubuhnya massif, membenamkan sebagian besar tubuhnya ke dalam substrat pasir, dan di tubuhnya banyak mengakumulasi pasir ataupun pecahan-pecahan karang maupun benda-benda padat lainnya. Selain itu, spons S. inconstans di dalam atau pada permukaan tubuhnya banyak terdapat cryptofauna asosiatif, seperti beberapa jenis cacing, krustasea, gastropoda, bivalvia, bintang mengular, dan invertebrata kecil lainnya (Palpandi et al., 2007).

Original name dari C. reinwardti adalah Clathria reinwardti Vosmaer, 1880, sedangkan Synonymised names-nya Clathria (Thalysias) spiculosa var. macilenta Hentschel, 1912 (junior synonym); Clathria reinwardti Vosmaer, 1880 (subgenus assignment); Clathria reinwardti var. subcylindrica Ridley, 1884 (junior synonym); Clathria typica var. porrecta Hentschel, 1912 (junior synonym); Rhaphidophlus reinwardti Vosmaer, 1880 (genus transfer); Rhaphidophlus seriatus Thiele, 1899 (genus transfer and junior synonym). Spons ini mampu mengakumulasi Cu dengan level tinggi, yaitu $161,3 \mathrm{mg} / \mathrm{kg}$ (Melawaty et al., 2014), mengandung jamur endofitik Mucor circineloides yang menghasilkan senyawa turunan poliketida dan kerangka benzofuran, yaitu senyawa bis2-etilheksil-tereftalat, dan tiga senyawa lainnya yang belum teridentifikasi. Di samping itu, senyawa diethyllene glycol dibenzoate dan dua fenvalerate isomers, serta dua senyawa lainnya dari diethylene glycol esters yang terdapat pada spons ini telah dievaluasi sebagai senyawa antimikroba dan senyawa yang memiliki aktifitas sebagai pestisida (Gout et al., 2005). C. reinwardti juga memiliki kemampuan yang tinggi (2 $\mathrm{mg} / \mathrm{kg}$ ) sebagai bioakumulator (zooremediator) logam berat Cobalt/Co (Melawat dan Pasau, 2014), memiliki mikrosimbion jamur strain actinomycete yang menghasilkan senyawa yang memiliki sitotoksisitas dan aktivitas antibakteri terhadap Escherichia coli dan Bacillus cereus (Chi et al., 2016).

Genus Spheciospongia yang berasal dari family Clionaidae dahulu dinamakan genus Spirastrella yang berasal dari family Spirastrellidae (Rutzler, 2002). Original name dari Spheciospongia inconstans Dendy, 1887 menurut World Register of Marine Species adalah Suberites inconstans Dendy, 1887, dan synonymised names-nya Spheciospongia arndti de Laubenfels, 1936 (junior synonym); Spirastrella inconstans (Dendy, 1887) (genus transfer); dan Suberites inconstans Dendy, 1887 (genus transfer). Spons ini memiliki bakteri simbion yang memiliki potensi untuk menghasilkan senyawa antibakteri yang paling aktif melawan fungi Candida albicans (Safaeian et al., 2002). Ekstraknya memiliki potensi sebagai senyawa antikanker, yang memiliki nilai $\mathrm{LC}_{50}$ dengan nilai toksisitas yang sangat tinggi, yaitu $85.4380 \mathrm{mg}^{-1} \mathrm{~L}^{-1}$ (Setiawan et al., 2002), berdasarkan analisis spectral GC-MS ekstrak kasarnya mengandung 19 senyawa dengan berbagai berat molekul. Ekstrak kasarnya memiliki sifat-sifat sebagai senyawa antimikroba, S. aureus, B. subtilis, E. coli, V. cholerae, dan C. albicans, dan memiliki sifat-sifat sebagai senyawa Antiplasmodial dengan LC 50 BSLT $109.4088 \mu \mathrm{g}$. $\mathrm{mL}^{-1}$ (Masteria, dkk., 2017).

Dengan melihat manfaat senyawa yang dikandung oleh spons $C$. reinwardti dan S. inconstans, serta keberlimpahannya di alam, khususnya di Pulau Barranglompo, penelitian ini dapat diketahui seperti apa keberlanjutan pemanfaatan kedua spons laut ini di masa sekarang dan di masa yang akan datang. Tujuan penelitian ini adalah mengetahui distribusi dan kerapatan spons jenis C. reinwardti dan S. inconstans di reef flat Pulau Barranglompo, Kepulauan Spermonde, Kecamatan Sangkarrang, Kota Makassar, sedangkan kegunaan penelitian ini adalah dapat dijadikan dasar untuk 
menentukan status keberlimpahan kedua spons ini untuk kepentingan pengelolaan dan pemanfaatannya.

\section{MATERI DAN METODE}

Penelitian ini dilaksanakan pada bulan Mei hingga November 2019 bertempat di Pulau Barranglompo, Kepulauan Spermonde, Kecamatan Kepulauan Sangkarrang, Kota Makassar, Indonesia (Gambar 1). Metode yang digunakan adalah belt transect (transek kuadran) dengan menggunakan roll meter sebagai acuan jarak. Titik awal roll meter $\pm 50 \mathrm{~m}$ dari garis pantai secara tegak lurus ditarik sampai batas akhir back reef sebanyak 3 (tiga) sub transek dengan jarak $\pm 50 \mathrm{~m}$ antar roll meter. Pada setiap interval $25 \mathrm{~m}$ pengamatan dilakukan menggunakan belt transect (transek kuadran) Ukuran $15 \mathrm{~m} \times$ $5 \mathrm{~m}$ sebagai Batasan pengamatan. Pada setiap transek kuadran, pertama-tama yang dilakukan adalah mengambil gambar setiap spons kemudian menghitung jumlah jenis yang terdapat pada setiap kuadran. Identifikasi spons dilakukan dengan cara mencocokkan hasil foto kamera bawah air dengan buku identifikasi spons. Identifikasi spons merujuk pada Bergquist, 1968, 1970; Bergquist \& Warne, 1980; Bergquist \& Fromont, 1988; Dawson, 1993; Kelly \& Herr, 2015; Levy, 1998. Setelah diketahui jenis sponsnya selanjutnya diklasifikasi menurut taksonomi sesuai pada World Register of Marine Species (WoRMS) yang dapat diakses di World Porifera Database pada (http://www. marinepecies.org/porifera/). Selanjutnya, untuk menghitung kerapatan jenis spons digunakan rumus Brower et al. (1998) dan untuk melihat perbedaan kerapatan spons antar stasiun digunakan uji statistik One-Way ANOVA dan disajikan dalam bentuk grafik.

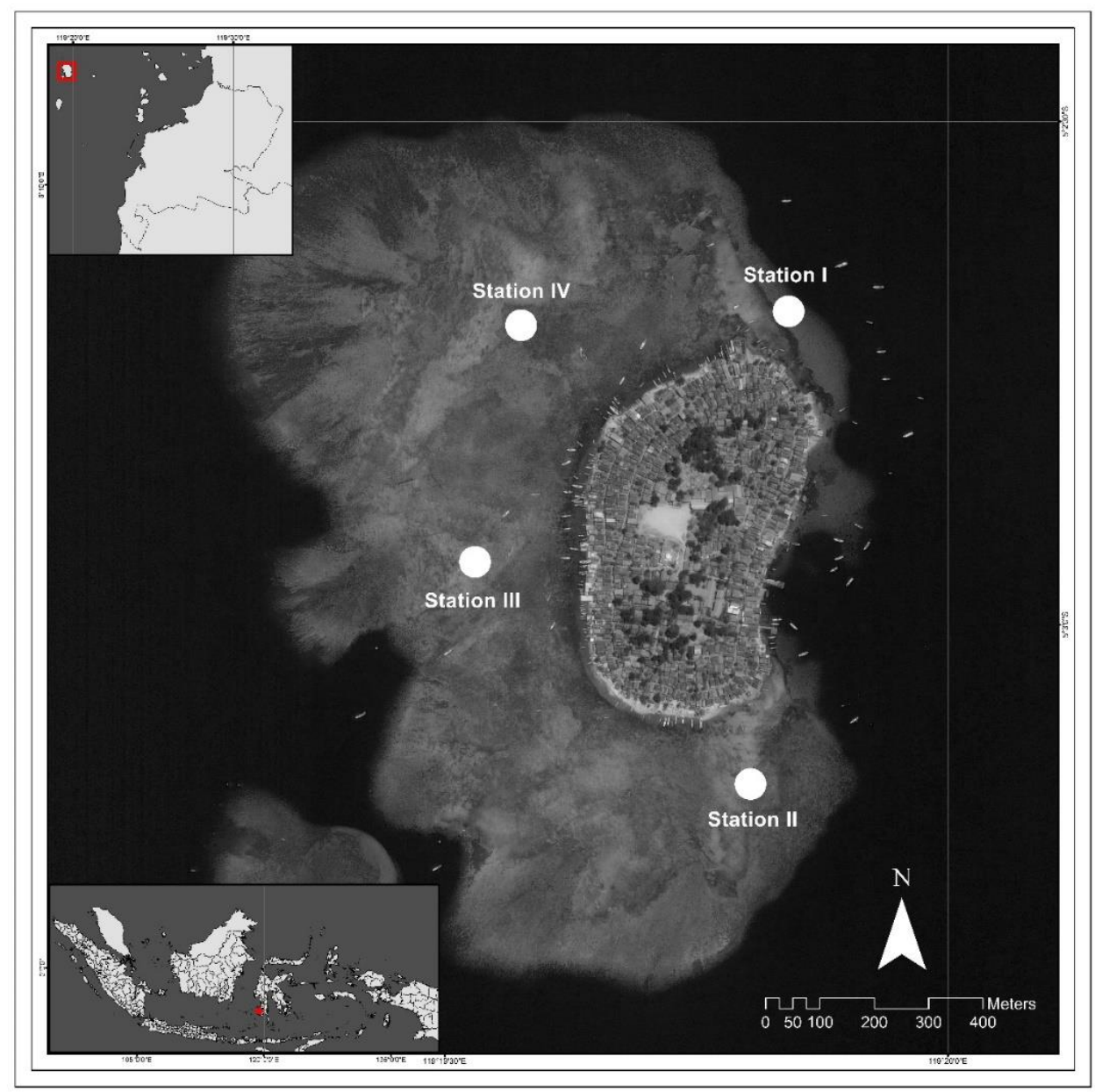

Gambar 1. Pulau Barranglompo, Kepulauan Spermonde, Kecamatan Sangkarrang, Kota Makassar, Indonesia 


\section{HASIL DAN PEMBAHASAN}

Kerapatan spons C. reinwardti (Gambar 2) tertinggi diperoleh di Stasiun IV sebesar 0,31 ind $/ \mathrm{m}^{2}$ dan terendah di Stasiun I sebesar 0,13 ind $/ \mathrm{m}^{2}$. Berdasarkan hasil uji statistik One Way ANOVA diperoleh nilai ( $F_{\text {hit }}=24,339$ dan $\mathrm{P}<0,05$ ) yang menunjukkan bahwa kerapatan C. reinwardti di stasiun I dan II berbeda nyata dengan stasiun III dan IV, di mana stasiun III dn IV lebih tinggi daripada stasiun I dan II, sedangkan kerapatan antar stasiun I dan II, dan antara stasiun III dan IV masing-masing tidak berbeda nyata (Gambar 3).

Tidak berbeda nyata kerapatan spons C. reinwardti antar stasiun I dan stasiun II, serta antar stasiun III dan IV diakibatkan oleh relative samanya kondisi lingkungan perairan pada stasiun I dan II dan pada stasiun III dan IV. Stasiun I dan II ini terletak di sisi leeward pulau, sedangkan stasiun III dan IV terletak di sisi windward pulau. Sisi leeward kondisi perairannya relatif tenang jika dibandingkan dengan sisi windward, sehingga dinamika dan sirkulasi massa airnya juga berbeda, di mana sisi leeward kurang berdinamika dan kurang bersirkulasi jika dibandingkan dengan sisi windward. Dinamika dan sirkulasi massa air penting bagi spons yang kebiasaan makannya menyaring makanan (filter feeders). Spons menyaring partikel-partikel organik maupun anorganik yang tersuspensi ataupun yang terlarut di dalam air. Semakin banyak massa air yang melewati permukaan tubuh spons, semakin banyak partikel organik ataupun anorganik yang tersaring, sehingga mempengaruhi rekrutmen, pertumbuhan, dan kerapatan spons di suatu tempat. Menurut Lesser dan Slattery (2013), spons adalah komunitas bentik penting pada ekosistem laut, dan memberikan hubungan fungsional yang sangat penting antara produktivitas kolom air dan hewan bentik. Sebagai pemakan suspensi yang aktif, spons memanfaatkan pikoplankton autotrophic dan heterotrophic yang melimpah di kolom air. Akibatnya spons yang hidup pada kondisi perairan yang selalu bergerak menunjukkan pola biomassa yang lebih besar dan konsisten tingkat keberadaannya. Demikian juga, pasokan makanannya yang berlimpah pada kondisi perairan yang selalu bergerak.
Faktor lainnya yang mengakibatkan kerapatan spons C. reinwardti pada stasiun I dan stasiun II lebih tinggi dan berbeda nyata daripada stasiun III dan stasiun IV adalah perbedaan substrat dasar di keduanya, di mana stasiun I dan stasiun II lebih didominasi oleh substrat pasir, sedangkan di stasiun III dan stasiun IV didominasi oleh vegetasi tumbuhan lamun, dan banyak bongkahan kerangka karang massif yang telah mati atau sebagian koloninya telah mati. Substrat pasir kurang cocok sebagai substrat pelekatan bagi larva spons yang akan mulai bertumbuh sebagai hewan bentik sesil, sedangkan substrat berupa tumbuhan lamun dan bongkahan karang mati massif atau bagian kerangka karang batu yang mati, sangat cocok sebagai substrat pelekatan larva spons. Menurut Marlow (2017), setiap peningkatan signifikan pada ketersediaan substrat berkapur yang terbuka karena kematian karang, cenderung menghasilkan peningkatan jumlah spons yang rekrut. Walan et al. (2008) juga mengatakan bahwa pada percobaan manipulatif yang menggunakan larva dari spons Rhopaloeides odorabile, didapatkan perilaku larva yang terkait dengan migrasi vertikal, fototaksis, dan kemampuan berenangnya, serta respon pelekatan untuk isyarat yang terkait dengan cahaya, mikro-topografi permukaan substrat, bongkahan karang dan biofilm. Selanjutnya Walan et al. (2014) mengatakan bahwa biofilm mikroba berperan penting dalam menginisiasi penempelan larva invertebrata laut. Biofilm mikroba laut menunjukkan variabilitas yang luar biasa dalam komposisi komunitas, dan seringkali dimediasi oleh kondisi lingkungan dan umur biofilm. Komposisi komunitas biofilm, sebagai hasil dari peningkatan suhu air laut dan usia biofilm, berkontribusi pada pengendapan larva spons dengan jumlah larva yang lebih tinggi yang mengendap ke biofilm. Biofilm mikroba umumnya banyak terdapat pada substrat yang stabil, seperti pada permukaan bongkahan karang mati dan lamun.

Perubahan komposisi spons mungkin sebagian disebabkan oleh fluktuasi besar dalam pengendapan sedimen yang disebabkan oleh perubahan arah angin dominan selama transisi dari musim kemarau ke musim hujan. Perubahan ini memicu 


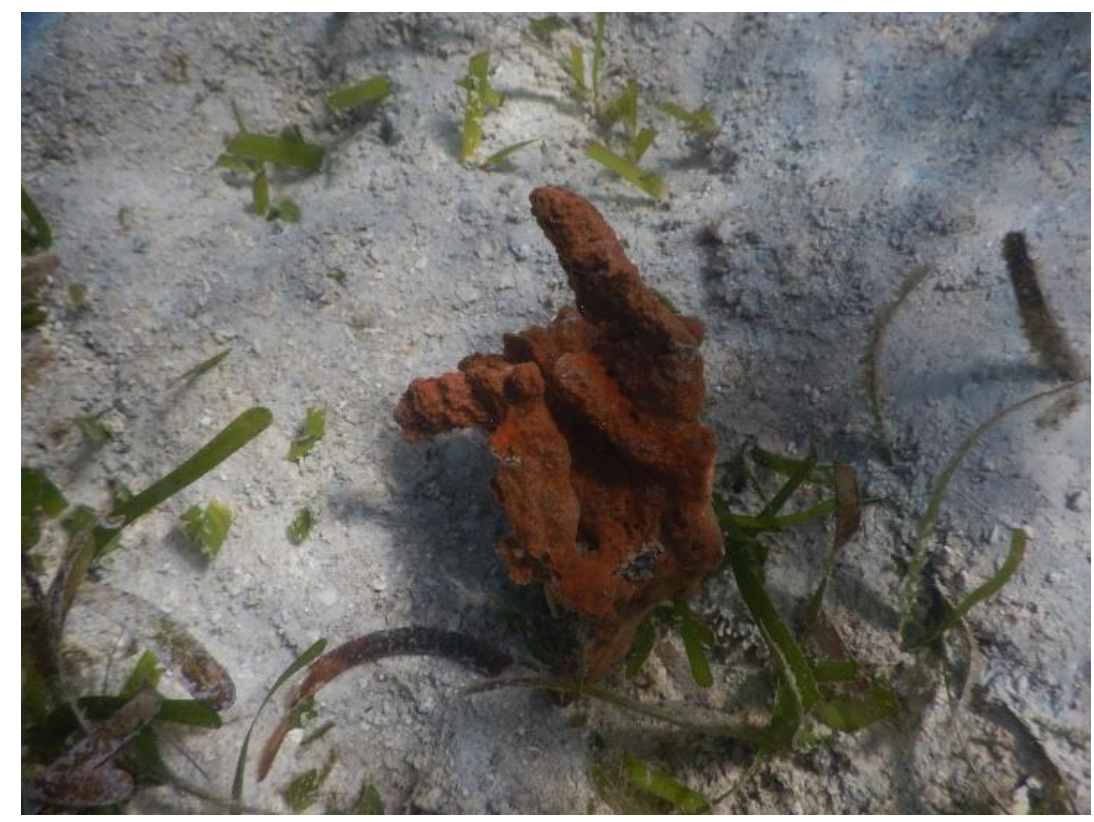

Gambar 2. Clathria reinwardti Vosmaer, 1880

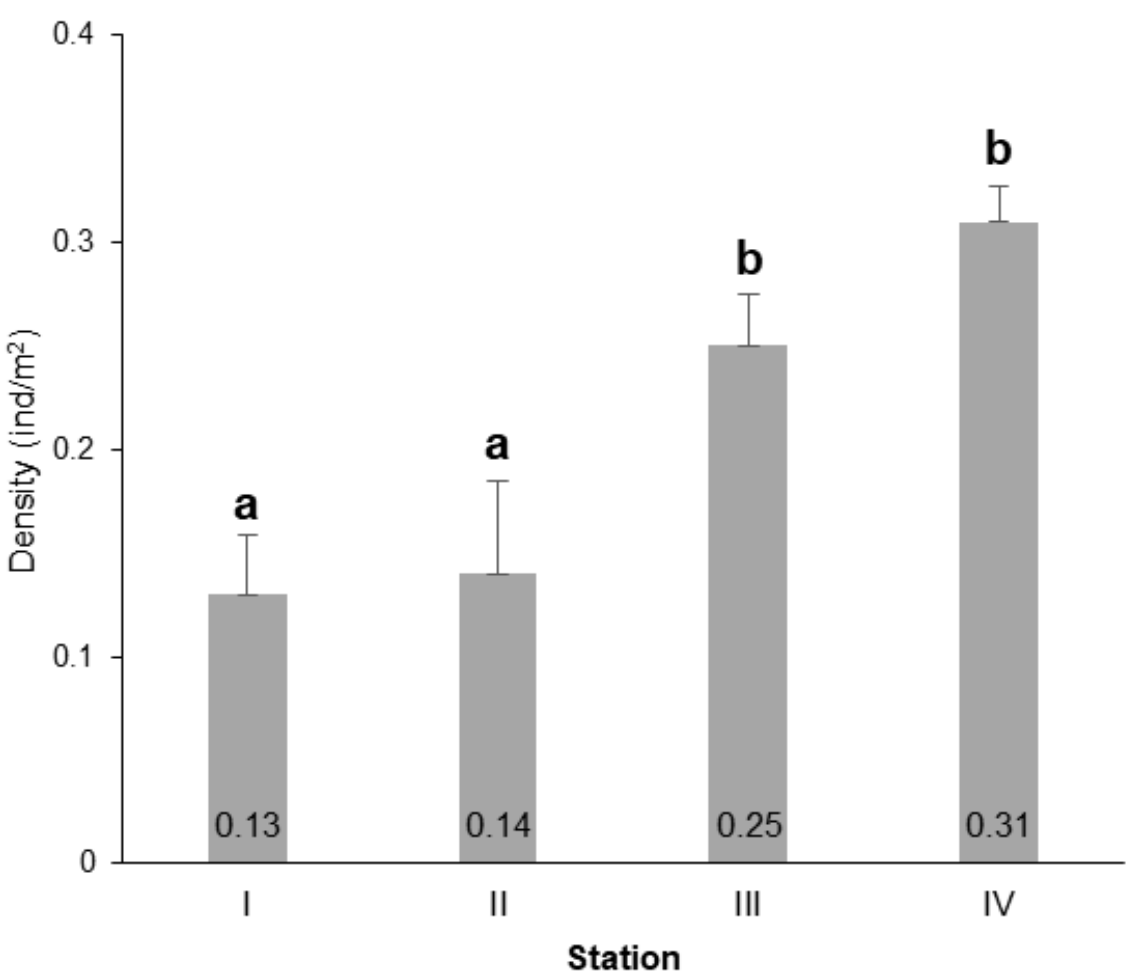

Gambar 3. Kerapatan Clathria reinwardti di reef flat Pulau Barranglompo

peningkatan sedimentasi/resuspensi dan pergerakan air di zona tersebut, yang merupakan faktor utama yang mempengaruhi struktur dan komposisi spons (Carballo, 2006).
Selain itu, spons dengan bentuk pertumbuhan bercabang mengalami stres dan kematian setelah menyaring Total Suspended Solid dan Bahan Organik Total selama 24 jam (Soeid et al., 2019). Hasil 
penelitian ini mengindikasikan bahwa $C$. reinwardti adalah spons yang tidak mampu bertahan hidup pada lingkungan perairan yang sedimentasi atau resuspensi tinggi. Secara morfologi, spons ini juga memiliki permukaan tubuh yang berlobus-lobus, sehingga sangat mudah sedimen hinggap di permukaan tubuhnya.

Kerapatan S. inconstans (gambar 4) tertinggi diperoleh di Stasiun III sebesar 0,67 ind $/ \mathrm{m}^{2}$ dan terendah di Stasiun I sebesar 0,02 ind $/ \mathrm{m}^{2}$. Berdasarkan hasil uji statistik One Way ANOVA diperoleh nilai $\left(F_{\text {hit }}=154,576\right.$ dan $\mathrm{P}<0,05$ ) yang menunjukkan bahwa kerapatan S. inconstans di setiap stasiun berbeda nyata (Gambar 5). Di habitatnya, spons ini secara sepintas tertanam pada substrat pasir, namun setelah pasir yang ada di sekitarnya disingkirkan, spons ini tetap melekat pada substrat yang keras, pada kerangka karang mati. Makanya pada hasil penelitian ini, kerapatannya pada substrat pasir, yang umumnya terdapat pada Stasiun I dan Stasiun II tergolong rendah. Spons ini didapatkan dengan kerapatan yang tinggi pada habitat yang banyak terdapat bongkahan karang-karang mati yang sudah tertimbun atau tertutupi pasir beberapa centimeter di atasnya. Mikro habitat yang seperti ini umumnya ditemukan pada padang lamun di daerah reef flat atau back reef. Karakter spons S. inconstans yang membenamkan sebagian tubuhnya ke dalam pasir adalah salah satu strategi untuk menghindari pemangsaan oleh hewanhewan pemakan spons (spongivory).
Kerapatan tertinggi spons $S$. inconstans di Pulau Barranglompo didapatkan pada Stasiun III kemudian di Stasiun IV. Di kedua stasiun ini hamparan padang lamunnya relatif luas dengan kerapatan lamun yang juga relatif tinggi, serta terdapat banyak bongkahan karang mati dan juga koloni karang batu yang toleran terhadap intensitas cahaya matahari yang tinggi, seperti karang Porites spp., Favia spp., Favites spp., dan juga karang bercabang Acropora spp. Penelitian yang dilakukan oleh Nasrawati \& Asmadin (2020), memperlihatkan korelasi positif antara kepadatan lamun dengan tingginya densitas spon di Kepulauan Wakatobi. Jenis spons yang ditemukan juga merupakan spons yang berasal dari kelas Demospongiae, yang sama dengan kelas spons yang diteliti pada penelitian ini.

Penyebab lain tingginya kerapatan spons pada Stasiun III dan Stasiun IV adalah relatif rendahnya resuspensi sedimen akibat adanya vegetasi lamun yang menutupi substrat pasir yang ada di sekitar lamun. Selain itu, vegetasi lamun juga dapat meredam energi gelombang, sehingga massa air lebih tenang, dan tidak menimbulkan resuspensi sedimen yang terdapat di dasar perairan. Resuspensi sedimen dapat menyebabkan kematian spons akibat isolasi sedimen pada permukaan tubuh spons. Isolasi sedimen dapat menutupi ostia spons akibat tertutup sedimen, dan lendir yang dihasilkan untuk menghalau sedimen juga dapat mengisolasi spons sehingga spons kekurangan oksigen dan makanan.

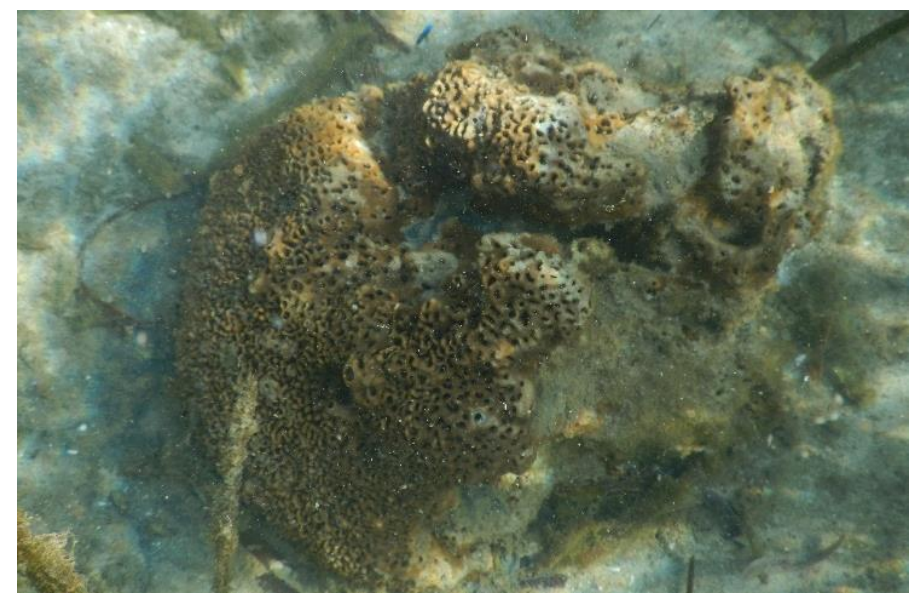

Gambar 4. Spheciospongia inconstans Dendy, 1887 


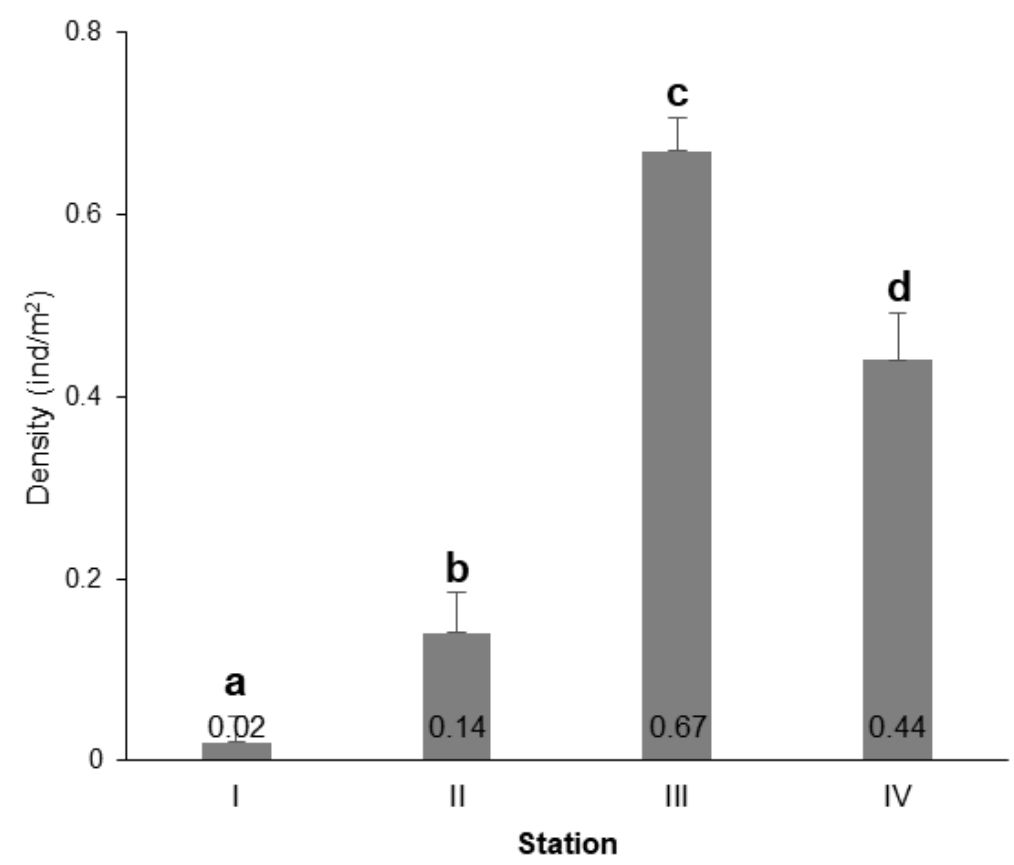

Gambar 5. Kerapatan Spheciospongia inconstans di reef flat Pulau Barranglompo

Penurunan kekeruhan dan koefisien atenuasi pada kolom air dapat meningkatkan ketersediaan cahaya yang sangat dibutuhkan oleh mikrosimbion spons untuk melakukan proses fotosintesis. Spons pada umumnya memiliki mikrosimbion berupa cyanobacteria yang berklorofil. Konstantinou et al. (2018) menemukan cyanobakteri Synechococcus, Leptolyngbyaceae, Pseudanabaenaceae, dan Schizotrichaceae pada 18 jenis spons di laut Mediterania; Thacker dan Starnes (2003) menemukan cyanobakteri berfilamen Oscillatoria spongeliae pada spons Dysidea spp. dan Ming Gao et al. (2017) menemukan cyanobakteri Candidatus Synechococcus spongiarum pada spons Dactylospongia elegans dari Laut Cina Selatan.

\section{KESIMPULAN}

Kerapatan spons Clathria reinwardti pada stasiun III $\left(0.25 / \mathrm{m}^{2}\right)$ dan stasiun IV $\left(0.31 / \mathrm{m}^{2}\right)$ di reef flat Pulau Barranglompo lebih tinggi dan berbeda nyata daripada stasiun I $\left(0.13 / \mathrm{m}^{2}\right)$ dan Stasiun II $\left(0.14 / \mathrm{m}^{2}\right)$, sedangkan kerapatan Spheciospongia inconstans tertinggi didapatkan pada stasiun III $\left(0.67 / \mathrm{m}^{2}\right)$, disusul kemudian stasiun IV $\left(0.44 / \mathrm{m}^{2}\right)$, stasiun $\|\left(0.14 / \mathrm{m}^{2}\right)$, dan stasiun 1 $\left(0.02 / \mathrm{m}^{2}\right)$. Kerapatan spons Spheciospongia inconstans di antara keempat stasiun tersebut berbeda nyata.

\section{UCAPAN TERIMA KASIH}

Penelitian ini didanai oleh dana penelitian hibah internal Universitas Hasanuddin dengan nomor kontrak 2006/UN4.1/KEP/2019 pada skim Penelitian Dosen Penasehat Akademik (PDPA) pada tahun 2019.

\section{DAFTAR PUSTAKA}

Brower, J.E., Zar, J.H. \& Von Ende, C.N., 1998. Field and Laboratory Methods of General Ecology. McGraw-Hill.

Carballo, J.L. 2009. Effect of natural sedimentation on the structure of tropical rocky sponge assemblages. Ecoscience, 13:119-130. doi: 10.2980/1195-6860(2006) 13[1 19:EONSOT]2.0.CO;2.

Chi, G.Y,, Ding, L.T., \& Tan. 2016. Biological and chemical analysis of actinomycetes associated with marine sponges from Singapore. Planta Medica, 82(S 01):p582

Goud, T., Krishnaiah, V.P., Reddy, S.M., Srinivasulu, M., Rao, M.R., \& Venkateswarlu, Y. 2005. Chemical investigation of the marine 
sponges Clathria reinwardti and Haliclona cribricutis. Indian Journal of Chemistry, 44B:607-610.

Hooper, J.N.A., Kennedy, J.A., \& van Soest, R.W.M. 2000. Annotated checklist of sponges (Porifera) of the South China Sea region. The Raffles Bulletin of Zoology, 8:125-207.

Konstantinou, D., Gerovasileiou, V., Voultsiadou, E., \& Gkelis, S. 2018. SpongesCyanobacteria associations: Global diversity overview and new data from the Eastern Mediterranean. PLOS ONE, 13(3): e0195001. doi: 10.1371/journal.pone.019 5001.

Levy, C. (Ed). 1998. Sponges of the New Caledonian Lagoon Collection Faune. Paris. ORSTOM.

Marlow, J. 2017. Sponge bioerosion and habitat degradation on Indonesian coral reefs. A thesis submitted to Victoria University of Wellington in fulfilment of the requirements for the degree of Doctor of Philosophy. pp. 223.

Melawat, L. \& Pasau, K. 2014. Essential Metal Co In Sponges (Porifera) from Spermonde Archipelago. International Journal of Scientific \& Technology Research, 3(10):246-248.

Melawaty, L., Noor, A., Harlim, T., \& de Voodg, N. 2014. The Potential of Clathria reinwardtii as bioaccumulator of heavy metal Cu. Jurnal Administrasi dan Kebijakan Kesehatan Indonesia, 15(2):1-3 doi: 10.20 956/mca.v15i2.1180.

Gao, Z.M., Zhou, G.W., Huang, H., \& Wang, Y. 2017. The Cyanobacteria-dominated sponge Dactylospongia elegans in the South China Sea: Prokaryotic Community and Metagenomic Insights. Frontiers in Microbiology, 8:p1387 doi : 10.3389/fmi cb. 2017.01387.

Nasrawati, I. \& Asmadin. 2020. Kepadatan spons pada ekosistem lamun kaitannya dengan parameter oseanografi di perairan Desa Kaswari Kabupaten Wakatobi. Sapa Laut, 5(4): 357-365.

Masteria, Y. \& Putra. \& Hadi, T. 2017. Chemical composition, antimicrobial, cytotoxic and antiplasmodial activities of three sponges from Buton Islands, Indonesia. Indonesian Journal of Marine Sciences, 22(3):147-154. doi : 10.14710/ik.jjms.22.3.147-154.

Palpandi, C., Ananthan, G., \& Shanmugam, A. 2007. Cryptofaunal Associates of Spirastrella inconstans (Dendy) and $S$. inconstans var. digitata (Dendy), the Coral Reef Sponges of Palk Bay. Journal of Fisheries and Aquatic Science, 2:71-76

Thacker R.W. \& Starnes, S. 2003, Host specificity of the symbiotic cyanobacterium Oscillatoria spongeliae in marine sponges, Dysidea spp. Marine Biology, 142: 643-648.

Safaeian, S.H., Hosseini, A.A.P., Asadolah, S., \& Farmohamadi. 2009. Antimicrobial activity of marine sponge extracts of offshore zone from Nay Band Bay, Iran. Journal de Mycologie Médicale, 19:1 1-16.

Setiawan, E., Nurhayati, N.J., de Voogd, A.T., Dewi, A., Alivy, L., Kartikasari, \& Subagio, I. 2002. Toxicity Test of Mangrove Epibiont Sponges in Tampora Situbondo using Brine Shrimp Lethality Test (BSLT)' Inventing Prosperous Future through Biological Research and Tropical Biodiversity Management AIP Conf. Proc., 2002, 020017-1-020017-5; doi : 10.1063/1. 5050113

Soeid, M., Haris, A. \& Syafiuddin .2019. The Ability of biofilter sponge Demospongiae class with various forms of growth towards the turbidity and total suspended solid. Torani. 2(2):87-94.

Whalan, S., Ettinger-Epstein, P., Battershill, C. \& de Nys, R., 2008. Larval vertical migration and hierarchical selectivity of settlement in a brooding marine sponge. Marine Ecology Progress Series, 368:145-154. 